\title{
Cytogenetic Analysis of Children with Ambiguous Genitalia in Mosul
}

\author{
Sada J. Abdulameer \\ Department of Biology \\ College of Science \\ University of Mosul
}

E.mail:sadaBio@yahoo.com

(Received 3/ 1/2012 ; Accepted 12/3/2012 )

\begin{abstract}
The present study aim to investigate the causes and characteristics of ambiguous genitalia in newborn who were referred to cytogenetic laboratory. Cytogenetic analysis was performed for each case. All cases were analyzed by chromosomal study using GTG karyotype. All patients after cytogenetic analysis revealed 46, XX and 46, XY Karyotype. One individual carry a Y chromosome but phenotypically female and one case have a female karyotype but are phenotypically male. The cytogenetic analysis of children with suspected chromosomal aberrations is important to uncover the contribution of chromosomal disorder in genesis of sexual ambiguity and congenital malformation in children and prevent further potentially unpleasant investigation being undertaken
\end{abstract}

Keywords: ambiguous genitalia, Cytogenetic analysis.

\section{تحالل الورلة الخلوبة للألفل النين ليهم غموضف الأعضاء التنلسلية لمدينة الموطل}

\section{الملهص}

تناولت هذه الدرلسة معرفة التركيب أو النط الورالثي للأطفل حديثي ال ـولادة مـ ع أع ـضاء تنلس لية

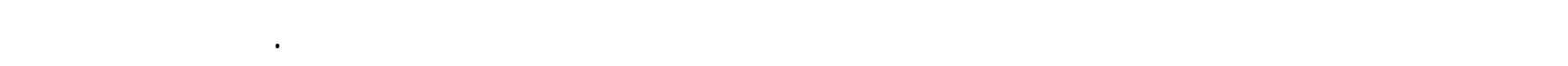

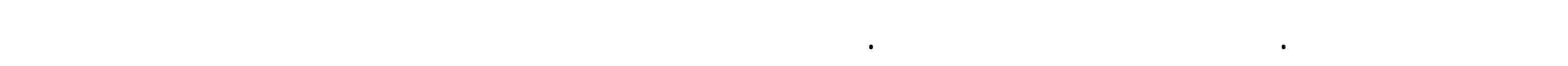
الحالات. لُٔلهرت النتائج 46XX , 46XY وهي نتيجةطبيعية لعدد الكروموسوملت للإنسان الطبيعي لكن الفرق

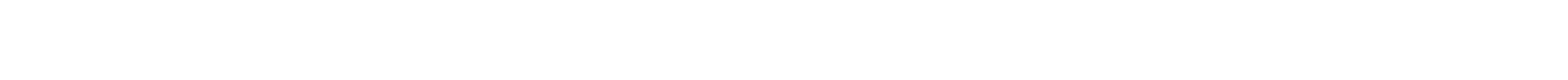

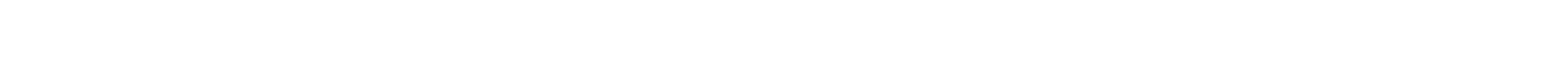
الفظهري نكر.

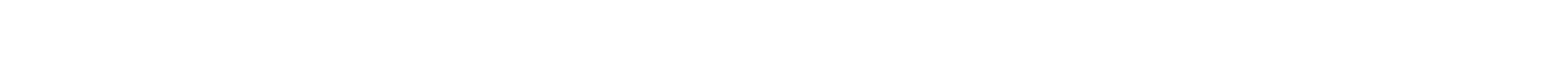

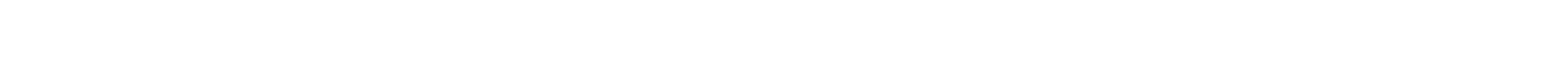

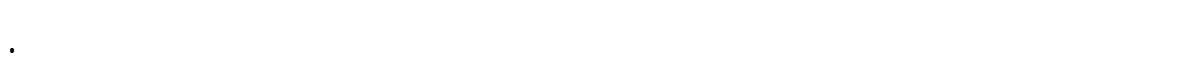




\section{INTRODUCTION}

Sexual ambiguity is a complex and often confusing medical problem in newborn. Determining the appropriate sex in these patients is an urgent matter, particularly in congenital adrenal hyperplasia (CAH) (Frimberger and Gearhart, 2005). Ambiguous genitalia in the newborn and children need immediate and rational management and assignment of sex for rearing should be guided by the etiology of the genital malformation (Sultan et al., 2002). The importance of the Y chromosome in male determination has been well established since the 1950's (Mendes et al., 1999). The main factor influencing the sex determination of an embryo is the genetic sex determined by the presence or absence of the $\mathrm{Y}$ chromosome (Ergun-Longmire et al., 2005). As a general rule, XY embryos become males and XX embryos become females. However, some individuals carry a Y chromosome but are phenotypically female (46,XY females) or have a female karyotype but are phenotypically male (46,XX males). $46, \mathrm{XX}$ maleness is a rare sex reversal syndrome affecting 1 in 20,000 newborn males. Molecular analysis of sex-reversed patients led to the discovery of the SRY gene (Berta et al., 1990). Human sexual differentiation is a highly complex process under the control of multiple genes and hormones. Abnormalities in normal sexual differentiation are relatively common and occur in approximately 1 per 4500 live birth. Human males with a 46,XX karyotype were first described in 1964 by three different groups of investigators (Sambrook and Fritsch, 1989). The present study aim to analyze the chromosomes of children those suffer from ambiguous genitalia in children during ( 2009-2011) in Mosul Iraq.

\section{MATERIALS AND METHODS}

A short term culture of peripheral blood lymphocytes $(5 \mathrm{ml})$ was collected in a heparinized syringe in the cytogenetic laboratory and culture was done by using $5 \mathrm{ml}$ of (RPMI-1640) media, $1 \mathrm{ml}$ fetal calf serum and $0.1 \mathrm{ml}$ of Phytohemagglutinin. The culture vials were kept in an incubator for 72 hours at $37 \mathrm{C}^{\circ}$. colcemid was added to arrest cell division at metaphase stage. Harvesting was done by adding $10 \mathrm{ml}$ of KCL ( $0.56 \%$ ) for 20 minutes. The cells were fixed with fixative 3:1 (methanol: acetic acid) after discarding the supernatant. The slides were prepared and stained with $4 \%$ Giemsa stain. Twenty well spread metaphases were screened under the light microscope X100 magnification. Microscopic examination cells were done after standard trypsin G-banding (GTG) (Yassen, 1990) was prepared by arranging homologous chromosomes in pairs according to international system for cytogenetic nomenclature (ISCN, 1995).

\section{RESULT}

This study was conducted in 20 children with age ranging from ten days to one year. All patients presented 46XX and 46XY karyotype at cytogenetic analysis. Clinical and cytogenetic finding of the patient are shown in Table (1). While in all patient were detected 46,XX and 46, XY Karyotype by cytogenetic analysis is one individual carrys a Y chromosome but phenotypically female or one of cases has a female karyotype but are phenotypically male such as in Fig. $(1,2)$. 
Table 1: Clinical and cytogenetic findings of the patients.

\begin{tabular}{|c|c|c|c|c|}
\hline Case & Age & Social sex & $\begin{array}{c}\text { External } \\
\text { genitalia }\end{array}$ & $\begin{array}{c}\text { Cytogenetic } \\
\text { Diagnosis }\end{array}$ \\
\hline 1 & 20 day & $\mathrm{M}$ & Ambiguous & $46, \mathrm{XY}$ \\
$2^{*}$ & 10 day & $\mathrm{F}$ & Ambiguous & $46 \mathrm{XY}$ \\
3 & 28 day & $\mathrm{F}$ & Ambiguous & $46 \mathrm{XX}$ \\
4 & 1 year & $\mathrm{F}$ & Ambiguous & $46 \mathrm{XX}$ \\
5 & 50 day & $\mathrm{F}$ & Ambiguous & $46 \mathrm{XX}$ \\
6 & 15 day & $\mathrm{M}$ & Ambiguous & $46 \mathrm{XY}$ \\
7 & 44 day & $\mathrm{M}$ & Ambiguous & $46 \mathrm{XY}$ \\
8 & 90 day & $\mathrm{F}$ & Ambiguous & $46 \mathrm{XX}$ \\
9 & 1 year & $\mathrm{M}$ & Ambiguous & $46 \mathrm{XY}$ \\
10 & 22 day & $\mathrm{M}$ & Ambiguous & $46 \mathrm{XY}$ \\
11 & 30 day & $\mathrm{F}$ & Ambiguous & $46 \mathrm{XX}$ \\
12 & 123 day & $\mathrm{F}$ & Ambiguous & $46 \mathrm{XX}$ \\
$13 *$ & 1 year & $\mathrm{M}$ & Ambiguous & $46 \mathrm{XX}$ \\
14 & 40 day & $\mathrm{F}$ & Ambiguous & $46 \mathrm{XX}$ \\
15 & 20 day & $\mathrm{F}$ & Ambiguous & $46 \mathrm{XX}$ \\
16 & 1 year & $\mathrm{F}$ & Ambiguous & $46 \mathrm{XX}$ \\
17 & 23 day & $\mathrm{F}$ & Ambiguous & $46 \mathrm{XX}$ \\
18 & 39 day & $\mathrm{M}$ & Ambiguous & $46 \mathrm{XY}$ \\
19 & 26 day & $\mathrm{F}$ & Ambiguous & $46 \mathrm{XX}$ \\
20 & 12 day & $\mathrm{F}$ & Ambiguous & $46 \mathrm{XX}$ \\
& & & & \\
& & & & \\
\hline
\end{tabular}

$\mathrm{F}=$ female, $\mathrm{M}=$ male

$*=$ case of ambiguous

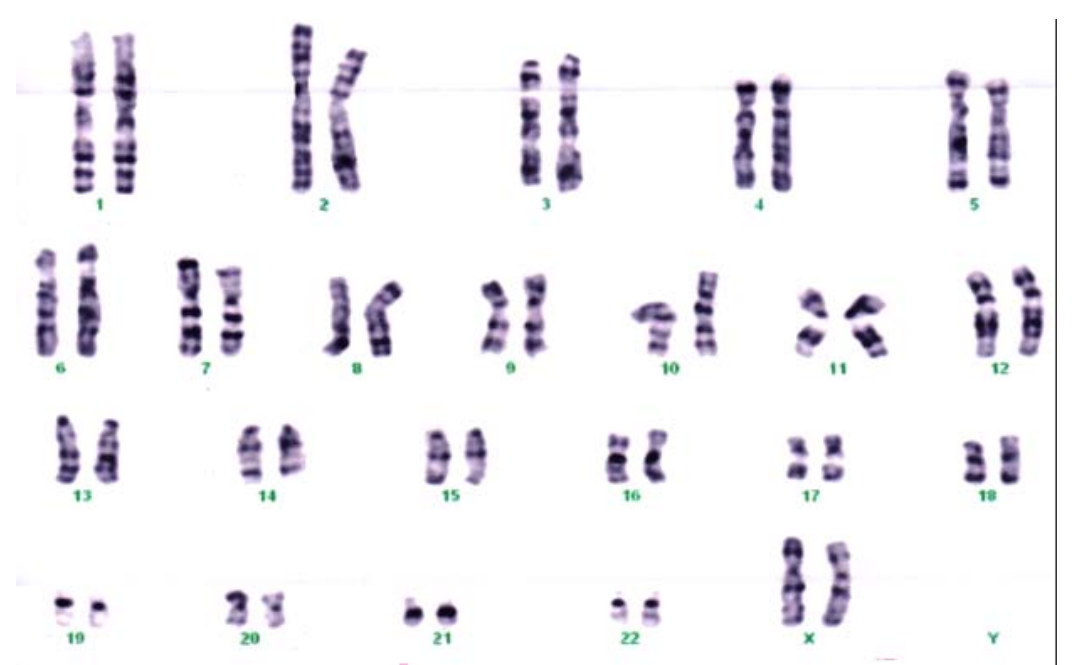

Fig. 1: Chromosomal analysis of ambiguous genitalia of female genotype but male phenotype. 


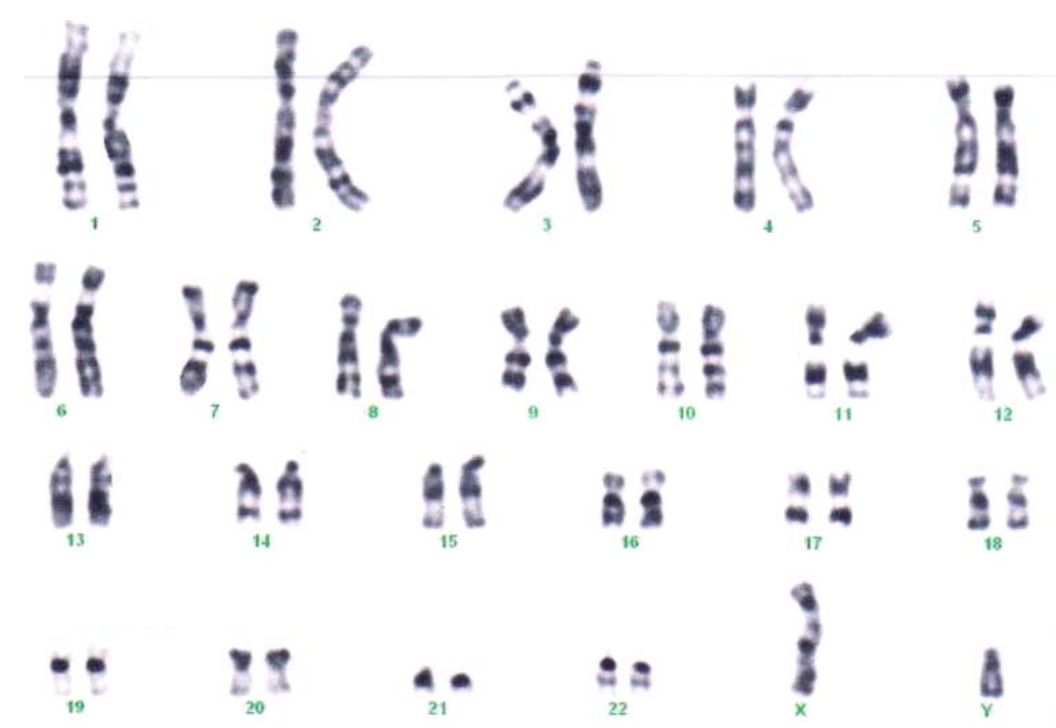

Fig. 2: Chromosomal analysis of ambiguous genitalia of male genotype but female
phenotype.

\section{DISCUSSION}

In this research was found from twenty cases are ambiguous genitalia two cases, were detected 46,XX and 46,XY Karyotype by cytogenetic analysis is one individual carrys a Y chromosome but phenotypically female and one of case have a female karyotype but are phenotypically male. Our study consistent with many studies. Human males with a 46,XX karyotype were first described in 1964 (Court-Brown et al., 1964 ; Rajender et al., 2006). The frequency of this syndrome has been estimated to be 1 in 20,000-25,000 newborn males, although there are considerable geographic variations molecular analyses have demonstrated that approximately $90 \%$ of patients with 46 , XXkaryotype carry a variable amount of $\mathrm{Y}$ material due to a Y-to-X interchange originated by an illegitimate recombination during paternal meiosis (Perez-Palacios and Kofman, 1994). In (Kusz et al., 1999) demonstrated that in XX males with Y-to-X translocations, preferential inactivation of the Y-bearing $\mathrm{X}$ chromosome could be the major mechanism causing a sexually ambiguous phenotype (Rajender et al., 2006). The origin of male phenotype in XX males could be the result of at least three different mechanisms: 1) translocation of $Y$ sequences, including the SRY gene, to an X chromosome or to an autosome; 2) a mutation in a yet unknown X-linked or autosomal gene in the testis-determining pathway, and 3) cryptic $\mathrm{Y}$ chromosome mosaicism (Zenteno-Ruiz et al., 2001). XX males can be classified as Ypositive or Y-negative depending on the presence or absence of Y-derived specific sequences.

In conclusion, the cytogenetic study at chromosomal level for new born with ambiguous genitalia need more investigation to supporting the result using PCR analysis of the SRY gene provides information about the presence of a Y chromosome within 1 day (Rajender et al., 2006). While we recommended the physician managing these families could minimize the trauma of having a child with unidentified sex by providing appropriate genetic counseling so that the parents can make an early decision. Prenatal DNA testing in at-risk families should be considered and appropriate therapy offered to minimize or prevent 
genital ambiguity. The birth of a newborn with ambiguous genitalia frequently comes as a surprise for the parents, therapist. Although some authors report that $60 \%$ of affected children are diagnosed prenatally, many parents are faced with the situation at birth (Frimberger and Gearhart, 2005). Physical examination is the key for diagnosis. Careful palpation to locate gonads at the genital folds or in the inguinal region provides the first element for diagnostic orientation. If gonads are absent, a diagnosis of female pseudohermaphroditism seems advisable; if gonads are palpated, a diagnosis of male pseudohermaphroditism is more appropriate(Rajender et al., 2006).

\section{ACKNOWLEDGEMENTS}

I would like to thank Dr. Muna A. Kashmoola in Medical College /Mosul University and Ibn Al-Atheer hospital for their kind help.

\section{REFERENCES}

Berta, P.; Hawkins, J. R.; Sinclair, A. H. (1990). Genetics evidence equaling sry and the testis determining factor. Nature.; 348, 448-450.

Court-Brown, W. M.; Harnden, D. G.; Jacobs, P. A.; Maclean, N.; Mantle, D.J. (1964). "Sex Chromosome Complement in Man". London : Her Majesty's Stationary Office: Medical Research Council, Special Report Series. 305 p.

Ergun-Longmire, B.; Vinci, G.; Alonso, L. ( 2005). Clinical, hormonal and cytogenetic evaluation of 46,XX males and review of the literature. J. Pediatr Endocrinol Metab.; 8,739-748.

Frimberger, D.; Gearhart, J. P. (2005). Ambiguous genitalia and intersex. Urol Int., 75, 291-297.

Kusz, K.; Kotecki, M.; Wojda , A. (1999). Incomplete masculinisation of XX subjects carrying the SRY gene on an inactive X chromosome. J. Med. Genet.; 36 (6), 452-456.

Mendes, J.R. (1999). Strufaldi MW, Delcelo R.; Y-chromosome identificatio by PCR and gonadal histopathology in Turner's syndrome without overt Ymosaicism. Clin. Endocrinol. (Oxf).; 50, 19-26.

International system for cytogenetic nomenclature (ISCN); (1995). "Chromosomal Study Nomenclature". N.Y. pp. 150-155.

Perez-Palacios, G.; Kofman, S. ( 1994). "Sex Reversal in Humans: The XX Male Syndrome and Related Disorders". In: Martinez- Mora J. (Editors). Textbook of Intersexual States. Barcelona, Spain: Doyma Press, 269 p.

Rajender, S .; Rajani, V.; Gupta, N. J. (2006). SRY-negative 46, XX male with normal genitals, complete masculinization and infertility. Mol. Hum. Reprod.; 12, 341-346.

Sambrook, J.; Fritsch, E. F. (1989). Maniatis T. Molecular cloning: A laboratory manual. Cold Spring Harbor Laboratory, 2, 1-1.

Sultan, C.; Paris, F.; Jeandel, C.; Lumbroso, S.; Galifer, R.B. ( 2002). Ambiguous genitalia in the new born. Semin. Reprod. Med.; 20, 181-188.

Yassen, N.Y. (1990). Cytogenetic study on human colorectal cancer cells. Ph. D. Thesis submitted University of Sheffield Medical School. pp. 44-46.

Zenteno-Ruiz , J. C.; Kofman-Alfaro, S.; Mendez, J.P. (2001 ). 46,XX Sex reversal. Arch . Med. Res.; 32, 559-566. 